\title{
PENINGKATAN PRODUKTIVITAS DAN KINERJA LINGKUNGAN DENGAN METODE GREEN PRODUCTIVITY DI PT. XYZ
}

\author{
AHMAD MUBIN DAN SYAIFUL ZAINURI \\ Jurusan Teknik Industri, Fakultas Teknik, Universitas Muhammadiyah Malang \\ Laman: ahmadmbn@ymail.com
}

\begin{abstract}
ABSTRAK
Produktivitas merupakan hal yang sangat penting bagi perusahaan sebagai salah satu cara untuk memantau kinerja produksinya. Pengukuran produktivitas dilakukan untuk mengetahui tingkat kinerja perusahaan dan dapat dijadikan sebagai pedoman untuk melakukan perbaikan secara terus-menerus. Demikian pula, aspek lingkungan telah menjadi isu penting dan strategis yang harus disikapi oleh industri dengan baik dan terus ditingkatkan kinerjanya. Agar perusahaan mampu meningkatkan produktivitas sekaligus menurunkan dampak lingkungan perlu digunakan pendekatan model Green Productivity. Tujuan penelitian ini yaitu mengidentifikasi faktor-faktor yang berpengaruh terhadap produktivitas dan kinerja lingkungan, serta memberikan usulan perbaikan menggunakan metode Green Productivity berdasarkan nilai indeks Benefit-Cost Ratio (BCR) tertinggi. Hasil penelitian menunjukkan bahwa faktor-faktor yang berpengaruh terhadap produktivitas dan kinerja lingkungan adalah kinerja ketel uap (boiler) dan penanganan limbah cair. Untuk mengatasi masalah tersebut, maka diperlukan suatu alternatif perbaikan. Alternatif perbaikan yang diusulkan adalah memasang Heat Exchanger dan DAF (Dissoveled Air Floatation). Dari hasil estimasi kontribusi, alternatif yang terpilih tersebut dapat memberikan peningkatan yang signifikan yakni indeks produktivitas ketel uap sebesar 103,64\% lebih baik daripada kondisi awal dan untuk indeks produktivitas limbah minyak sebesar 104,18\% lebih baik daripada kondisi awal, serta terjadi penurunan kadar CO sebesar 0,19 dan kadar minyak dan lemak sebesar 0,17.
\end{abstract}

Kata kunci: Produktivitas, Kinerja Lingkungan, Green Productivity, Benefit-Cost Ratio.

\begin{abstract}
Productivity is very important for the company as a way to monitor the production performance. Productivity measurement is performed to determine the level of productivity performance of the company and can be used as guideline for continuous improvement. Similarly, the environmental aspect has become an important and strategic issues that must be addressed by the industry well and improved its performance continuously. In order to improve productivity while lowering environmental impact the company need to use Green Productivity model approach. The purposes of this research were to identify factors that affect productivity and environmental performance, as well as providing proposed improvement using Green Productivity method based on the highest value of the Benefit-Cost Ratio (BCR) index. The results showed that the factors that affect productivity and environmental performance are the boiler performance and the wastewater treatment. Therefore to overcome these problems, it was needed an improvement alternative. The improvement alternative proposed were to install Heat Exchanger and DAF (Dissoveled Air Floatation). From the estimated contribution, the chosen alternative could provide a significant increase in the productivity index of boiler at $103.64 \%$ better than the initial condition and productivity index of oil waste by $104.18 \%$ better than the initial condition, also there were decreased level of CO level at 0.19 and 0.17 for oil and fat.
\end{abstract}

Key words: Productivity, Environmental Performance, Green Productivity, Benefit-Cost Ratio

\section{PENDAHULUAN}

Industri dapat menjadi sumber kemakmuran bagi suatu bangsa. Industrialisasi telah menempati posisi sentral dalam ekonomi dan masyarakat saat ini dan merupakan motor penggerak yang memberikan dasar bagi peningkatan kemakmuran umat manusia. Banyak kebutuhan manusia hanya dapat dipenuhi oleh barang dan jasa yang disediakan dari sektor industri (Kristanto, 2001). Aspek lingkungan telah menjadi isu penting dan strategis harus disikapi oleh industri dengan baik, jika semula bersikap reaktif dalam menghadapi isu lingkungan, maka saat ini harus diubah menjadi lebih proaktif dan antisipatif (Ciptomulyono, 2001). Sikap proaktif dan antisipatif tersebut selanjutnya diwujudkan dalam upaya secara terus menerus peningkatan kinerja lingkungan. Keuntungan bagi perusahaan dalam pengelolaan lingkungan adalah dapat meningkatkan kepercayaan 
konsumen, memberikan citra baik kepada produsen, dan meningkatkan efisiensi agar mampu bersaing di pasar global.

Menurut Nasution (2006) produktivitas didefinisikan sebagai hubungan antara input dan output suatu sistim produksi. Hubungan ini sering lebih umum dinyatakan sebagai rasio output dibagi input. Jika lebih banyak output yang dihasilkan dengan input yang sama, maka disebut terjadi peningkatan produktivitas. Begitu juga kalau input yang lebih rendah dapat menghasilkan output yang tetap, maka produktivitas dikatakan meningkat. Dengan diketahuinya produktivitas, maka akan diketahui pula seberapa efisien sumber-sumber input telah berhasil dihemat. Produktivitas merupakan hal yang sangat penting bagi suatu perusahaan sebagai salah satu cara untuk memantau kinerja produksinya, selain sebagai sarana untuk mempromosikan produk atau jasa yang dihasilkan. Pengukuran produktivitas dilakukan untuk mengetahui tingkat kinerja perusahaan dan dapat dijadikan sebagai pedoman untuk melakukan perbaikan secara terus-menerus (Iriani, 2006; Ika dan Moses, 2012).

Suatu pendekatan yang tepat untuk membantu perusahaan agar mampu meningkatkan produktivitas sekaligus menurunkan dampak lingkungan adalah dengan model Green Productivity (GP). Green Productivity adalah strategi peningkatan produktivitas bisnis dan kinerja lingkungan secara bersamaan, untuk keseluruhan pembangunan sosial-ekonomi. Penerapan GP merupakan teknik, teknologi, dan sistim manajemen yang tepat untuk menghasilkan barang dan jasa yang ramah lingkungan (APO, 2003; APO, 2008). Pendekatan metode ini, diharapkan dapat mengevaluasi dan memberikan alternatif-alternatif solusi perbaikan untuk peningkatan produktivitas dan kinerja lingkungan di masa mendatang sehingga perusahaan akan mampu meningkatkan produktivitas dan kinerjanya dalam pengelolaan lingkungan. Penerapan GP akan memungkinkan terjadinya eco-efficiency yang pada akhirnya mengarah pada tercapainya pembangunan berkelanjutan (sustainable development) yaitu pembangunan yang dapat memenuhi kebutuhan generasi saat ini tanpa mengorbankan kemampuan dan kesempatan generasi mendatang untuk memenuhi kebutuhannya (Djajadiningrat dan Famiola, 2004; Sugandhy dan Hakim, 2007).

Konsep Green Productivity sangat menarik karena menggabungkan upaya peningkatan produktivitas dan penanggulangan terhadap dampak lingkungan untuk mencapai pembangunan berkelanjutan. Green Productivity merupakan salah satu konsep peningkatan produktivitas yang berorientasi kepada pemeliharaan lingkungan dan didasarkan atas keseimbangan antara peningkatan produktivitas dan pembangunan berkelanjutan.

Adapun tujuan dari penelitian ini adalah mengidentifikasi faktor-faktor yang berpengaruh terhadap produktivitas dan kinerja lingkungan, dan memberikan usulan perbaikan menggunakan metode Green Productivity berdasarkan nilai indeks Benefit Cost Ratio (BCR) tertinggi. Hasil penelitian ini diharapkan dapat memberikan gambaran mengenai tingkat produktivitas perusahaan dan dampak lingkungan yang ditimbulkan dari proses produksi, sehingga dapat dijadikan dasar untuk melakukan perbaikan dan peningkatan produktivitas dan penurunan dampak lingkungan akibat limbah yang dihasikan.

\section{METODE}

Penelitian ini dilakukan melalui lima tahapan yaitu tahap pendahuluan, tahap pengumpulan data, pengolahan data, tahap analisis data, dan tahap penarikan kesimpulan. Pada tahap pendahuluan yang merupakan langkah awal dari penelitian dengan melakukan studi lapangan dan studi pustaka. Studi lapangan bertujuan mengetahui kondisi riil perusahaan khususnya proses yang banyak menghasilkan limbah. Setelah memperoleh gambaran dari survei awal dan mengetahui kendala-kendala yang dihadapi oleh perusahaan, maka dilakukan studi pustaka untuk mendukung penelitian yang akan dilakukan sehingga penelitian tersebut mempunyai dasar teori yang terarah dan memberikan hasil pemecahan yang optimal.

Tahap pengumpulan data yaitu melakukan pengambilan data dengan wawancara dan pengamatan langsung. Data tersebut meliputi gambaran umum perusahaan, proses produksi, input dan output hasil produksi, rekapan hasil analisis kandungan zat kimia, dan penyebaran kuisioner. Kuisioner dimaksudkan untuk menentukan nilai bobot (weight) dari tingkat bahaya setiap zat kimia terhadap parameter keseimbangan lingkungan dan kesehatan manusia. Responden penelitian adalah ahli kimia lingkungan.

Tahap pengolahan data yaitu melakukan pengolahan data yang dikumpulkan untuk mendapatkan hasil sesuai dengan tujuan yang telah ditetapkan. Pengolahan data tersebut meliputi pengukuran tingkat produktivitas, perhitungan indeks Environmental Performance Indicator (EPI), identifikasi faktor-faktor yang mempengaruhi tingkat produktivitas dan kinerja lingkungan serta penyusunan alternatif-alternatif perbaikan, pemilihan alternatif perbaikan berdasarkan nilai 
indeks Benefit Cost Ratio (BCR) tertinggi, estiminasi kontribusi alternatif terpilih terhadap produtivitas dan kinerja lingkungan, dan penyusunan rencana implementasi.

Pengukuran produktivitas dilakukan dengan membagi antara output total dengan input total yang meliputi penggunaan material, biaya tenaga kerja, dan penggunaan energi. EPI merupakan tolak ukur kinerja dan performansi lingkungan suatu perusahaan. Indeks EPI dihitung melalui perkalian antara bobot (weight) tingkat bahaya suatu zat kimia dengan prosentase penyimpangan jumlah kandungan zat kimia dalam limbah. Identifikasi faktor-faktor yang mempengaruhi tingkat produktivitas dan kinerja lingkungan yaitu mencari faktor-faktor apa saja yang mempengaruhi tingkat produktivitas dan kinerja lingkungan dengan menggunakan diagram sebab akibat. Setelah itu, menyusun beberapa alternatif-alternatif perbaikan yang disesuaikan dengan tujuan yang telah ditetapkan.

Pemilihan alternatif perbaikan berdasarkan nilai indeks Benefit Cost Ratio (BCR) tertinggi. Dalam memilih alternatif solusi yang telah dimunculkan pada tahap sebelumnya dengan mempertimbangkan indeks BCR. Nilai perbandingan ini menunjukkan besarnya manfaat yang akan diperoleh perusahaan dibandingkan pengeluaran yang dibebankan. Pemilihan alternatif didasarkan atas nilai BCR yang paling tinggi.

Estiminasi kontribusi alternatif terpilih terhadap produtivitas dan kinerja lingkungan. Setelah menemukan alternatif terbaik dan melakukan analisis teknisnya, selanjutnya dibuat estiminasi peningkatan terhadap angka produktivitas serta indeks EPI. Ini merupakan salah satu tujuan utama konsep Green Productivity, yaitu senantiasa meningkatkan produktivitas namun tetap memperhatikan kinerja lingkungan. Selanjutnya, penyusunan rencana implementasi yang merupakan kelanjutan dari analisis kelayakan teknis, dimana akan dibuat jadwal rencana implementasi.

Pada tahap analisis dilakukan analisis dan pembahasan dari hasil pengolahan data. Sebagai tahap akhir, yaitu tahap penarikan kesimpulan hasil penelitian yang dilakukan.

\section{HASIL DAN PEMBAHASAN}

Penelitian ini dilakukan di PT. XYZ yang terletak di Kabupaten Malang. Visi perusahaan adalah sebagai perusahaan terbaik dalam bidang agro industri, siap menghadapi tantangan dan unggul dalam kompetisi global, bertumpu pada kemampuan sendiri (own capabilities), dan misinya adalah menjadi perusahaan dengan kinerja terbaik dalam bidang agro industri, yang dikelola secara profesional dan inovatif dengan orientasi dengan kualitas produk dan pelayanan pelanggan yang prima (exellent costumer service) sebagai karya sumberdaya manusia yang handal, mampu tumbuh dan berkembang memenuhi harapan pihak berkepentingan terkait (stake holders).

Limbah industri yang dihasilkan PT XYZ terdiri atas limbah padat, limbah cair berupa air pendingin mesin, dan pendingin pada unit pembangkit listrik, blow down dari ketel, akan tercampur bersama air buangan dari air pendingin mesin, dan limbah gas berupa asap dan jelaga hasil pembakaran. Untuk menanggulangi terbawanya jelaga keluar cerobong, maka digunakan dust collector yang kedalamnya disemprotkan air sehingga jelaga dapat mengendap ke bawah (Wet Dust Collector). Tetapi proses ini masih memerlukan penyempurnaan karena masih adanya jelaga yang terbawa keluar cerobong.

\section{Perhitungan Tingkat Produktivitas}

Produktivitas diperoleh dengan membandingkan antara output total dengan input total. Faktor input meliputi input material utama dan input produksi, sedangkan faktor output merupakan output hasil produksi (dalam rupiah). Perhitungan tingkat produktivitas total perusahaan menggunakan persamaan sebagai berikut:

Indeks Produktivitas Total $=\frac{\text { Total Output }}{\text { Total Input }} \times 100 \%$

Hasil perhitungan indeks produktivitas PT XYZ dapat dilihat pada Gambar 1.

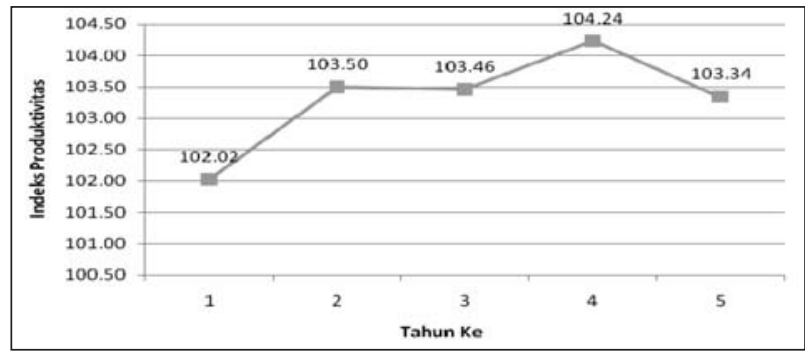

Gambar 1. Dinamika Indeks Produktivitas PT XYZ

Berdasarkan Gambar 1, diketahui bahwa produktivitas PT XYZ mengalami penurunan pada tahun terakhir sebesar 0,9\%, hal ini dikarenakan indeks produktivitas total pada tahun terakhir lebih kecil dari indeks produktivitas total pada tahun sebelumnya.

\section{Perhitungan Indeks Environmental Performance Indicator (EPI)}

Tidak ada dasar yang tetap (konsisten) dalam pemilihan indikator-indikator, jumlah indikator ataupun teknik-teknik pengukuran dan ketentuan 
standar. EPI merefleksikan efisiensi lingkungan dari sebuah proses produksi yang melibatkan jumlah input dan output. Karakter-karakter EPI yaitu (a) relevansi, (b) keakuratan analisis, (c) dapat diukur (measurebility), dan (d) dapat dibandingkan (comparability).

Perhitungan indeks EPI dilakukan dengan mengalikan nilai penyimpangan antara standar BAPEDAL dengan hasil analisis perusahaan dengan bobot dari masing-masing kriteria limbah yang diperoleh melalui penyebaran kuisioner.

Indeks EPI dihitung dengan rumus:

Indeks EPI $=\sum_{i=1}^{k} W_{i} \cdot P_{i}$

Dimana Wi merupakan bobot variabel ke- $i$ yang diperoleh dari kuesioner, sedangkan untuk nilai Pi merupakan prosentase penyimpangan antara standar BAPEDAL dengan PT XYZ, dengan rumus:

$\mathrm{P}=\frac{\text { Standar }- \text { hasil Analisa }}{\text { Standar }} \times 100 \%$

Untuk mengetahui tingkat bahaya dari masingmasing parameter bagi manusia dan lingkungan diperlukan kuisioner guna pembobotan Environmental Performance Indicator (EPI). Pembobotan EPI dilakukan melalui penyebaran kuisioner kepada 12 orang responden. Skala penilaiannya adalah 1-5, dimana semakin besar nilainya, maka semakin besar pula bahayanya bagi manusia dan lingkungan. Berdasarkan hasil uji validity dan reliability diketahui bahwa kuisioner yang dibuat valid dan reliable, yang berarti bahwa kuisioner yang sama dapat diberikan kepada responden yang lain tanpa memberikan tingkat penyimpangan yang signifikan. Hal ini ditunjukkan oleh nilai alpha yang lebih besar daripada nilai $r$ tabel sebesar 0,3981 .

Hasil perhitungan diperoleh nilai indeks EPI masing-masing kriteria sebagaimana pada Tabel 1. Berdasarkan hasil tersebut, total indeks EPI PT XYZ bernilai positif yaitu sebesar 16,64; artinya bahwa secara umum kandungan zat-zat kimia tersebut dalam limbah telah memenuhi standar maksimum yang telah ditentukan. Akan tetapi, dari 7 parameter zat-zat kimia tersebut, terdapat beberapa zat kimia yang mempunyai nilai penyimpangan $(\mathrm{Pi})$ tinggi antara lain kadar minyak sebesar 90,38\% dengan indeks EPI 2,98, CO sebesar 98,94\%, dengan indeks EPI 3,52, dan kadar $\mathrm{SO}_{2}$ sebesar 99,44\% (hampir 100\%) dengan indeks EPI $4,06 \%$. Hal ini menunjukkan bahwa ketiga zat kimia tersebut memiliki tingkat bahaya yang tinggi bagi manusia dan lingkungan. Semua zat kimia yang terkandung dalam limbah ini dapat memberikan dampak bagi lingkungan (menyebabkan polusi) dimana ketiga zat kimia tersebut dapat menyebabkan iritasi, kanker, sesak napas, kejang, dan hilangnya kesadaran serta berakibat pada tanaman antara lain, dengan gejala beberapa daun memucat, kering dan akhirnya mati.

\section{Identifikasi Faktor-Faktor yang Berpengaruh}

Dalam Green Productivity, diagram sebabakibat sangat bermanfaat untuk mengilustrasikan dengan jelas macam-macam penyebab yang dapat mempengaruhi limbah produksi yang dihasilkan. Mesin boiler di stasiun milling memiliki fungsi sebagai sumber energi utama (penghasil uap kering) yang digunakan untuk mengoperasikan sebagian besar mesin-mesin yang ada di lantai produksi. Tidak stabilnya suhu pada superheater menyebabkan uap kering yang dihasilkan rendah sehingga tidak mampu untuk menggerakkan turbin-turbin. Hal ini disebabkan tidak adanya alat kontrol temperatur untuk mengetahui temperatur air pada superheater. Selama ini pengecekan temperatur hanya dengan mengalirkan uap basah dan membuka starting valve. Disamping itu, rendahnya mutu bahan bakar mengakibatkan proses pembakaran tidak maksimal dan suhu kalor yang dihasilkan rendah.

Dari proses pelumasan turbin dan mesin, minyak yang dihasilkan tidak bisa diolah, dikarenakan tidak adanya saluran khusus untuk pembuangan ke kolam

Tabel 1. Hasil Perhitungan Indeks EPI

\begin{tabular}{lccccc}
\hline \multicolumn{1}{c}{ Parameter } & $\begin{array}{c}\text { Bobot } \\
(\mathbf{W i})\end{array}$ & Standar Bapedal & Hasil Analisis & $\begin{array}{c}\text { Penyimpangan } \\
(\mathbf{P i})\end{array}$ & $\begin{array}{c}\text { Indeks EPI } \\
\text { (Wi.Pi) }\end{array}$ \\
\hline $\mathrm{BOD}_{5}$ & 3,50 & $21,1 \mathrm{mg} / \mathrm{l}$ & $10 \mathrm{mg} / \mathrm{l}$ & $52,61 \%$ & 1,84 \\
$\mathrm{COD}$ & 3,17 & $41,7 \mathrm{mg} / 1$ & $21 \mathrm{mg} / 1$ & $49,64 \%$ & 1,57 \\
$\mathrm{TSS}$ & 3,38 & $20,8 \mathrm{mg} / 1$ & $6 \mathrm{mg} / \mathrm{l}$ & $71,15 \%$ & 2,40 \\
Minyak \& Lemak & 3,29 & $20,8 \mathrm{mg} / 1$ & $0,2 \mathrm{mg} / \mathrm{l}$ & $90,38 \%$ & 2,98 \\
Sulfida & 4,08 & $0,208 \mathrm{mg} / 1$ & $0 \mathrm{mg} / \mathrm{l}$ & $0,00 \%$ & 0,00 \\
$\mathrm{CO}$ & 3,58 & $1000 \mathrm{mg} / \mathrm{m}^{3}$ & $15,21 \mathrm{mg} / \mathrm{m} 3$ & $98,47 \%$ & 3,52 \\
$\mathrm{SO}_{2}$ & 4,08 & $800 \mathrm{mg} / \mathrm{m}^{3}$ & $4,48 \mathrm{mg} / \mathrm{m} 3$ & $99,44 \%$ & 4,06 \\
\hline \multicolumn{7}{r}{} \\
\hline
\end{tabular}


limbah. Sehingga perlu dilakukan perbaikan pada proses pengolahan limbah cair tersebut dengan penambahan alat baru agar dapat menurunkan kadar minyak yang terkandung dalam limbah hasil produksi.

Berikut ini penyebab-penyebab yang mempengaruhi tingkat produktivitas dan kinerja lingkungan, yaitu permasalahan pada ketel uap (boiler) pada Gambar 2 dan permasalahan pada limbah cair pada Gambar 3.

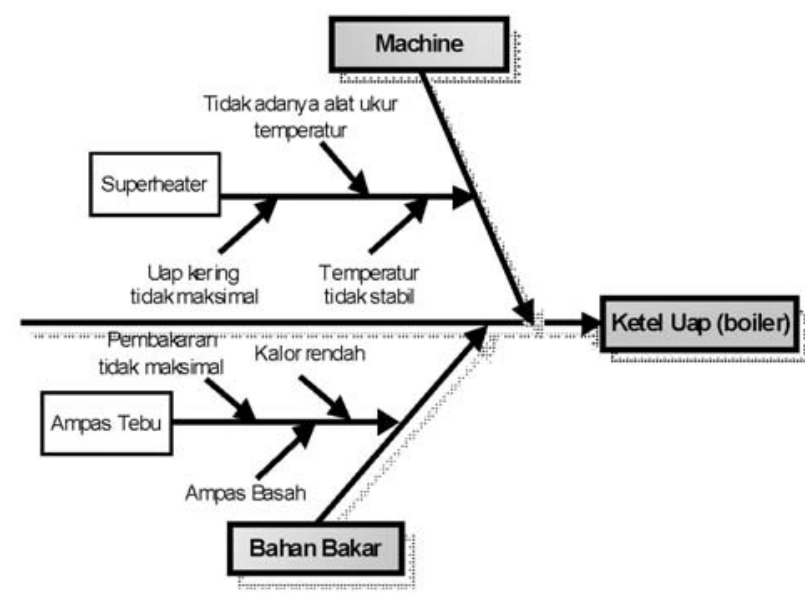

Gambar 2. Diagram Sebab-Akibat pada Ketel Uap (boiler)

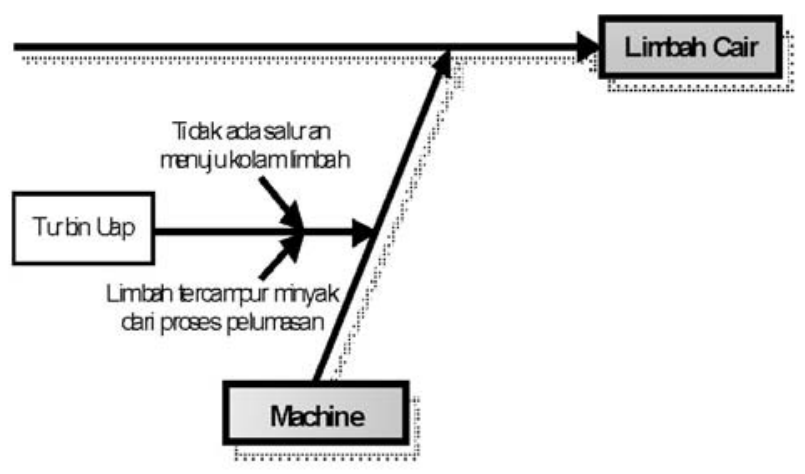

Gambar 3. Diagram Sebab-Akibat Permasalahan Limbah Cair

Berdasarkan diagram sebab-akibat pada Gambar 2 dan 3, maka faktor-faktor yang mempengaruhi tingkat produktivitas dan kinerja lingkungan adalah: (1) tidak stabilnya suhu bahan ketel uap (boiler), yakni tidak adanya alat kontrol temperatur untuk mengetahui temperatur air pada superheater. Selain itu, mutu bahan bakar rendah mengakibatkan kalor pembakaran pada mesin boiler yang dihasilkan rendah, dan (2) limbah cair yang dihasilkan, yakni adanya minyak dari proses pelumasan mesin dari turbin yang terikut disalurkan ke limbah.

\section{Penyusunan Alternatif Solusi}

Berdasarkan pada hasil analisis diagram sebab akibat, diperoleh beberapa pilihan solusi dari dua permasalahan yang penting yang dialami oleh PT XYZ agar dapat melakukan penerapan Green Productivity, yaitu pertama, permasalahan di ketel uap. Dari permasalahan di ketel uap (Boiler) diperoleh dua alternatif yang dapat mengatasi permasahan tersebut meliputi: (1) alat pengontrol temperatur dan penambahan bahan bakar serbuk kayu. Tidak stabilnya suhu pada superheater menyebabkan uap kering yang dihasilkan rendah sehingga tidak mampu untuk menggerakkan turbin-turbin. Untuk mengatasi masalah tersebut diperlukan suatu alat untuk mengotrol suhu yaitu dengan pemasangan alat ukur panas (Heat Exchanger). Alat ini terdiri atas sebuah shell yang didalamnya berisi banyak tabung-tabung kecil yang sumbunya sejajar dengan sumbu shell. Disamping itu dilakukan penambahan bahan bahar berupa serbuk kayu yang memiliki kalor pembakaran yang tinggi. Adapun tujuan dari penambahan bahan bakar serbuk kayu untuk meringankan beban bahan bakar karena kalor yang dihasilkan lebih tinggi, dan (2) alat pengontrol temperatur dan penambahan bahan bakar minyak bakar. Tidak stabilnya suhu pada superheater menyebabkan uap kering yang dihasilkan rendah sehingga tidak mampu untuk menggerakkan turbinturbin. Untuk mengatasi masalah tersebut diperlukan suatu alat untuk mengotrol suhu yaitu dengan pemasangan alat ukur panas (Heat Exchanger). Tetapi sebagai bahan bakar tambahan digunakan minyak bakar dengan nilai kalor pembakaran yang cukup tinggi sehingga beban bahan bakar ketel sangat rendah dan meningkatkan air kondensat yang bisa dimanfaatkan untuk menangkap abu ketel (Wet Dust Coller).

Permasalahan kedua yaitu limbah cair. Adanya minyak dari proses pelumasan mesin dari turbin yang terikut disalurkan ke limbah perlu dipisahkan secara maksimal untuk mengurangi bahaya limbah minyak dan juga penghematan kebutuhan minyak pelumas sehingga bisa terjadi penghematan dari segi biaya. Untuk mengatasi permasalahan tersebut diperoleh dua alternatif, meliputi: (1) bak penangkap minyak, yang berfungsi untuk memisahkan minyak dengan air secara perbedaan densitas (massa jenis) yaitu minyak berada di atas dan air berada di bawah. Di kolam penangkap minyak, minyak yang berada di bagian atas bak tersebut akan mengalir secara overflow. Selanjutnya disalurkan kembali ke tempat penampungan minyak gelincir, sehingga kebutuhan minyak gelincir bisa dihemat, dan 
(2) memasang DAF (Dissoveled Air Floatation). DAF adalah seperangkat alat pemisah minyak dari air dimana alat DAF dilengkapi tangki resentasi yang berfungsi mengontakkan udara yang bertekanan untuk mengapungkan minyak didalam limbah yang kemudian ditangkap dengan scraper sehingga minyak akan dialirkan melalui saluran yang sudah dibuat untuk dipakai ulang dan cairannya akan dialirkan ke proses selanjutnya di Unit Pengolahan Limbah Cair (UPLC).

\section{Pemilihan Alternatif Perbaikan Berdasarkan Nilai Benefit-Cost Ratio (BCR) Tertinggi}

Hasil penyusunan alternatif diatas dapat dipilih satu alternatif sehingga dapat membantu perusahaan mengatasi masalah dengan biaya yang minimal. Adapun data-data yang dibutuhkan untuk menentukan alternatif yang akan dipakai nantinya di perusahaan yaitu data biaya investasi awal, biaya operasional dan biaya penghematan.

Pada permasalahan pertama, indek rasio BCR alternatif I

$=\frac{\text { Benefit }}{\text { Cost }}=\frac{166 \cdot 675.966}{494.272 .302}=0,33$

dan indek rasio BCR alternatif II

$=\frac{\text { Benefit }}{\text { Cost }}=\frac{507.138 .171}{494.272 .302}=1,03$

Berdasarkan hasil perhitungan indeks BCR pada permasalahan yang pertama, maka terpilih alternatif II (memasang Heat Exchanger dan bahan bakar alternatif minyak bakar) karena indeks BCR alternatif II sebesar 1,03 lebih besar dari alternatif I (memasang Heat Exchanger dan bahan bakar alternatif serbuk kayu) dengan indeks BCR 0,33. Hal ini dikarenakan, hasil bahan bakar yang digunakan yaitu minyak bakar lebih baik dan lebih ramah lingkungan dari pada memakai serbuk kayu.

Berdasarkan hasil perhitungan indeks BCR pada permasalahan yang kedua, maka terpilih alternatif II memasang DAF (Disssoveled Air Floatation) dengan indeks BCR 1,24 lebih besar dari alternatif I memasang bak minyak dengan indeks BCR 0,99, hal ini dikarenakan, hasil pengolahan untuk mengambil minyak lebih cepat terpisah.

Nilai indeks BCR $>1$ menunjukkan bahwa biaya yang harus ditanggung oleh perusahaan lebih kecil dari pada keuntungannya. Demikian pula, dengan menaati peraturan pemerintah tentang perlindungan lingkungan maka besarnya biaya yang ditanggung sebagai konsekuensi dari pengendalian limbah dan perlindungan lingkungan.

\section{Estimasi Kontribusi Alternatif Terpilih}

Untuk mengetahui seberapa besar peningkatan produktivitas yang dapat dicapai oleh alternatif terpilih yakni alternatif II, maka dapat dilakukan estimasi berdasarkan penghematan yang dapat diperoleh.

Hasil estimasi kontribusi solusi terhadap produktivitas dan kinerja lingkungan menunjukan bahwa solusi yang terpilih tersebut memberikan peningkatan bagi produktivitas dan kinerja lingkungan yang dinyatakan sebagai indeks EPI sebagaimana diperlihatkan pada Tabel 2 .

Tabel 2. Estimasi peningkatan produktivitas dan kinerja lingkungan

\begin{tabular}{lcc}
\hline \multicolumn{1}{c}{ Perbaikan } & Kondisi Awal & Estimasi \\
\hline $\begin{array}{l}\text { Indeks Produktivitas } \\
\text { (Ketel Uap) }\end{array}$ & $103,36 \%$ & $103,64 \%$ \\
$\begin{array}{l}\text { Indeks Produktivitas } \\
\text { (Limbah Minyak) }\end{array}$ & $103,36 \%$ & $104,18 \%$ \\
Indeks EPI & 16,37 & 16,56 \\
\hline
\end{tabular}

\section{Rencana Implementasi}

Hasil pemilihan alternatif pada permasalahan pertama yaitu alternatif II, selanjutnya dapat disusun rencana implementasi perbaikan sebagaimana diperlihatkan pada Tabel 3. Hasil pemilihan alternatif pada permasalahan kedua yaitu alternatif II, selanjutnya dapat disusun rencana implementasi alternatif II sebagaimana diperlihatkan pada Tabel 4.

Tabel 3. Rencana Implementasi Perbaikan pada Permasalahan Pertama (Ketel Uap)

\begin{tabular}{clll}
\hline No & \multicolumn{1}{c}{ Tujuan } & \multicolumn{1}{c}{ Target } & \multicolumn{1}{c}{ Tindakan } \\
\hline 1 & $\begin{array}{l}\text { Menurunkan penggunaan } \\
\text { bahan bakar pada proses } \\
\text { produksi }\end{array}$ & $\begin{array}{l}\text { Mengidentifikasi bahan bakar } \\
\text { di ketel uap dan pemasangan }\end{array}$ & $\begin{array}{l}\text { Menaikan suhu fresh water boiler dan } \\
\text { menambahkan bahan bakar alternatif } \\
\text { HE }\end{array}$ \\
$\begin{array}{llll}\text { Menurunkan dampak } \\
\text { limbah udara terhadap } \\
\text { lingkungan }\end{array}$ & $\begin{array}{l}\text { Mengurangi asap pembakaran } \\
\text { pada ketel boiler }\end{array}$ & $\begin{array}{l}\text { Menaikan suhu feed water boiler dan } \\
\text { menambahkan IDO sebagai bahan bakar } \\
\text { alternatif }\end{array}$ & Departemen produksi \\
\hline
\end{tabular}


Tabel 4. Rencana Implementasi Perbaikan pada Permasalahan Kedua (Limbah Cair)

\begin{tabular}{cllll}
\hline No & \multicolumn{1}{c}{ Tujuan } & \multicolumn{1}{c}{ Target } & \multicolumn{1}{c}{ Tindakan } & Pelaksanaan \\
\hline 1 & $\begin{array}{l}\text { Memperbaiki buangan limbah } \\
\text { cair }\end{array}$ & $\begin{array}{l}\text { Menurunkan kandungan minyak } \\
\text { pada limbah cair }\end{array}$ & Memasang bak penangkap minyak & Departemen limbah \\
2 & $\begin{array}{l}\text { Memperbaiki buangan limbah } \\
\text { cair }\end{array}$ & $\begin{array}{l}\text { Menurunkan kandungan minyak } \\
\text { pada limbah cair }\end{array}$ & $\begin{array}{l}\text { Memasang DAF (Dissoveled Air } \\
\text { Floatation) }\end{array}$ & Departemen limbah \\
\hline
\end{tabular}

\section{SIMPULAN}

Berdasarkan hasil analisis dapat disimpulkan bahwa faktor yang berpengaruh terhadap produktivitas dan kinerja lingkungan perusahaan adalah kinerja ketel uap (boiler), dan pengolahan limbah cair. Berdasarkan nilai indeks Benefit Cost Ratio (BCR) tertinggi, maka alternatif perbaikan yang diusulkan adalah pemasangan Heat Exchanger dan penambahan bahan bakar minyak dan pemasangan DAF (Dissoveled Air Floatation). Dari hasil estimasi kontribusi, alternatif yang terpilih tersebut dapat memberikan peningkatan produktivitas dan kinerja lingkungan dibandingkan dengan pada kondisi awal.

\section{DAFTAR PUSTAKA}

Asian Productivity Organization (APO), 2003. A Measurement Guide to Green Productivity. Tokyo.

Asian Productivity Organization (APO), 2008. Green Productivity (GP) and Green Supply Chain (GSC) Manual. Tokyo.
BAPEDAL Jatim, 2002. Keputusan Gubernur Jatim No. 45 Tahun 2002 tentang Baku Mutu Limbah Cair Bagi Industri atau Kegiatan Usaha Sendiri.

Ciptomulyono, U., 2001. Eco-Manufacturing: Paradigma Menuju Industri yang Berwawasan Lingkungan. Makalah Seminar Nasional Strategi Manufaktur. ITS. Surabaya.

Ika, P.D. dan Moses L.S., 2012. Implementasi Green Productivity sebagai Upaya untuk Meningkatkan Produktivitas dan Kinerja Lingkungan. http:// digilib.its.ac.id/public/ITS-Undergraduate 70542502109010- makalah.pdf. Diakses pada 1 Oktober 2012.

Iriani, 2006. Alternatif Solusi Pengurangan Limbah pada Perusahaan dengan Penerapan Green Productivity. Jurnal Teknik Kimia, 1 (1).

Djajadiningrat, S.T., dan Famiola M., 2004. Kawasan Industri Berwawasan Lingkungan (Eco-Industrial Park). Rekayasa Sains. Bandung.

Kristanto, P., 2001. Ekologi Industri. Andi. Yogyakarta.

Nasution, A.H., 2006. Manajemen Industri. Andi. Yogyakarta.

Sugandhy, A. dan Hakim R., 2007. Prinsip Dasar Kebijakan Pembangunan Berkelanjutan Berwawasan Lingkungan. Bumi Aksara. Jakarta. 